\title{
EXPERIENCES OF PRE-PRIMARY EDUCATION TEACHERS IN ASSESSING CHILDREN'S ACHIEVEMENTS AND PROGRESS IN DISTANCE EDUCATION DURING THE COVID-19 PANDEMIC
}

\author{
Aida Norviliene ${ }^{1}$, Sada RamanauskienE $^{2}$, Neringa StrazdienĖ $^{3}$, Rasa BraslauskienE ${ }^{4}$, Reda JacynE ${ }^{5}$ \\ Klaipeda University (Lithuania)
}

\begin{abstract}
The Covid-19 pandemic posed new challenges and opportunities for participants in education. The following article reveals the experiences of pre-primary education teachers in assessing children's achievements and progress in distance education during the first lockdown of the Covid-19 pandemic. The qualitative research involved 15 pre-primary education teachers who worked remotely in the spring of 2020. The method of semi-structured interview was chosen. The continuity of education was found to be maintained. All activities were transferred to distance education by emphasising the opportunity for parents to engage, interest and motivate children. Various tools for distance education were used: online platforms and social networks, general digital software, and specialised software for the creation and demonstration of teaching materials. The assessment of children's achievements and progress in distance education is seen by teachers as a complex process that requires a high level of parental involvement.

KEY WORDS: Covid-19 pandemic, pre-primary education, distance education, assessment of children's achievements and progress.
\end{abstract}

JEL CODES: I21, I25.

DOI: http://dx.doi.org/10.15181/rfds.v34i2.2251

\section{Introduction}

The Covid-19 pandemic posed new challenges and opportunities for participants in education (heads of educational institutions, teachers, students and their parents). The sudden transformation of teaching/learning caused by the global pandemic allows us to examine the possibilities of adapting distance education to ensure children's involvement, provision of personalisation, timely feedback, and assessment of children's achievements and progress,

Aida Norvilienè - lecturer, doctor of social sciences, Klaipèda University, Faculty of Social Sciences and Humanities Scientific interests: development of teacher competencies, pre-school and primary education, education management, study quality E-mail: aida.norviliene@ku.lt

Tel. +37065615640

2 Sada Ramanauskiené - associate professor, doctor of social sciences, Klaipeda University, Faculty of Social Sciences and Humanities Scientific interests: childhood education, Jewish ethno-pedagogy, history of education

E-mail: sada.ramanauskiene@gmail.com

Tel. +37061542097

3 Neringa Strazdienè - professor, doctor of social sciences, Klaipeda University, Faculty of Social Sciences and Humanities Scientific interests: creation of teaching and learning environments, child health education

E-mail: n.strazdiene@gmail.com

Tel. +37046398624

4 Rasa Braslauskiené - professor, doctor of social sciences, Klaipéda University, Faculty of Social Sciences and Humanities Scientific interests: organisation of the study process, teacher training, social and family policy

E-mail: rasa.braslauskiene@gmail.com

Tel. +370 46398631

5 Reda Jacyne - associate professor, doctor of social sciences, Klaipeda University, Faculty of Social Sciences and Humanities Scientific interests: contemporary educational theories, curriculum management and innovation, teacher training E-mail: vismantiene.r@gmail.com

Tel. +37046398624 
by ensuring the academic integrity and quality of education. The Covid-19 pandemic has substantially affected every area of human life: from the economy, medicine and education, to daily life, social relations and vocabulary. Many of us began to commonly use words such as 'Teams', 'Zoom', etc, in everyday speech (Dwivedi et al., 2020). Masonbrink and Hurley (2020) suggest paying attention to the importance of ensuring that students have reliable access to technology, stable learning environments, the assessment of children's achievements and progress in the face of possible lockdowns and closure of educational institutions. Sintema (2020) notes that prior to the Covid-19 pandemic, research seldom focused on the impact of global pandemics on education.

The 'Programme of the Government of the Republic of Lithuania' (2020) pays special attention to highquality education that is accessible to all. Recently, in the field of pre-school education, the issue of the quality of educational services has been specially analysed and discussed. It was important for a number of factors related to the elements of change in the child's social role, the representation of the interests of the users (students' parents) of educational services, and the transfer and application of principles of universal quality in the pre-primary age children's education sector. The following is especially relevant when assessing the teaching/learning situation during the Covid-19 pandemic.

Many Lithuanian and foreign researchers have studied the assessment, documentation and information of the child's achievements under the usual conditions of the educational institution: Alasuutari, Markstrom (2011), Boyd (2011), Brenneman (2011), Bernotienè, Juraitienè (2011), Diamond, Justice, Siegler and Snyder (2013), Gerde, Schachter and Wasik (2013), Indrašienė, Žibẻnienè (2014), Ramanauskienė, Norvilienė (2017), and others.

The situation with distance education during the Covid-19 pandemic was analysed from various points of view. The professional activities of educators working in the conditions of the Covid-19 pandemic was analysed by: Bertling, Rojas, Alegre and Faherty (2020), Donohue, Johnson, Lucas, Lynd, Mukerjee and Thouvenelle (2020), and Di Pietro, Biagi, Costa, Karpiński and Mazza (2020). The likely impact of Covid-19 on education: reflections based on the existing literature and international datasets (Pokhrel, Chhetri, 2021). Difficulties experienced by teachers, aspects of the newly reorganised educational process, and newly acquired skills, as well as guidelines for further work, are analysed: Schleicher (2020), International Task Force on Teachers for Education 2030 (2021), Covid-19: A global Crisis for Teaching and Learning (2020), Technical Note Education during the Covid-19 Pandemic, Version 1 (2020). Yoshikawa, Wuermli, Britto et al. (2020), Verma and Priyamvada (2020), and in the project 'Distance Education of Children during the Covid-19 Pandemic: Threats and Opportunities from an Ecosystem Perspective' (2020) carried out by Vilnius University researchers. The following articles and reports provide recommendations for teachers, administrators in educational institutions, and parents.

Issues related to progress and evaluation changes while working remotely are discussed in the work of the following authors, and research data are presented in the following documents: Reimers (2020), Guidelines on Distance Education during COVID-19 (2020), and Policy Brief: Education during Covid-19 and beyond (2020). According to Reimers (2020), the Covid-19 situation and changes in the educational reality raise fundamental questions in the professional perspective of educators. Many of the functions performed by educators are changing, or rather are moving into virtual reality. Brown, Te Riele, Shelley and Woodroffe (2020) argue that teachers are well versed in the development of targeted learning experience to meet clear objectives and evaluations of the curriculum. However, the transfer of all learning to distance learning requires time, a lot of additional knowledge, and assistance from professionals in other fields. Azevedo et al. (2020) emphasise that the damage caused by the Covid-19 pandemic and its phenomena to children's teaching/learning is already clearly visible.

Even though a review of the scientific literature suggests that the Covid-19 situation and changes in the educational process are analysed, it can be noted that the field of pre-primary education is little studied. There is no research that reveals the experiences of pre-primary education teachers about the assessment of children's progress and achievements in distance learning. The assessment of achievements is very important for the improvement of the educational process, because the quality of education is also assessed in view of children's achievements. Continuous research data show that high-quality early childhood education helps to solve many social problems, such as poverty and unemployment, reduces dependencies, improves academic achievement, and has a positive impact on the quality of life (Quality of Pre-primary Education, 2012; Proposal for a Council Recommendation on High Quality Early Childhood Education and Care Systems, 2018). 
Guidelines for the assessment of pre-primary children's achievements and progress and other educational elements are established by the General Curriculum of Pre-primary Education (hereinafter the Programme), which was prepared and published in 2014 during the implementation of a project financed by the European Social Fund and State Budget of the Republic of Lithuania. Pre-primary education has been compulsory in Lithuania since 2016. The programme indicates that the assessment of children's achievements plays a crucial role in achieving the intended goal. The assessment is based on the long-term observation of the child, and the collection and summary of information from a variety of sources. The programme identifies five competencies: social, health, cognitive, communicative and creative. Areas of education assigned to each competence are indicated. The achievements of each competence are divided into provisions, abilities, knowledge and understanding specific to the intended area of education; educational guidelines are indicated. The optimal level (according to individual abilities) of educational achievements-competencies forms and ensures the school maturity of a child. The programme states that the level of competence is revealed when a child acts in a natural or purposefully created situation: while playing, communicating, participating in project activities, during picnics, excursions, or the like. All the mentioned provisions are a guide for the pre-primary education teacher to how the assessment of each child's achievements and progress should be planned, organised, implemented and documented. During the lockdown, with the move to distance learning, conditions for the assessment of children's achievements and progress changed significantly. The article raises problematic questions: how pre-primary education teachers assessed the achievements and progress of students, and what experiences were gained during the lockdown due to the Covid-19 pandemic in distance learning.

Research object: experiences of pre-primary education teachers in assessing children's achievements and progress in distance learning due to the lockdown during the Covid-19 pandemic.

The aim of the research is to investigate the opinion of pre-primary education teachers about their experiences of distance learning in assessing children's achievements and progress during the first lockdown in the Covid-19 pandemic.

Research methods: analysis of scientific literature and documents, qualitative research, semi-structured interview, qualitative content analysis.

\section{Research methodology}

A qualitative research methodology was chosen to reveal the experiences of pre-primary education teachers in assessing children's achievements and progress in distance education during the first lockdown due to the Covid-19 pandemic (Creswell, 2014; Žydžiūnaitè, Sabaliauskas, 2017). The method of semi-structured interview was chosen. When planning the research questions, six topics were identified: situation assessment (in the context of administration and staff); organisation of teaching/learning activities when conducting distance learning; assessment of children's achievements and progress in the analysed situation; feelings, experiences of teachers, children and parents; advantages and disadvantages of distance pre-primary education; and preparation strategy by anticipating distance education in the future. The philosophy of dialogue is very important in relation to the educational situation analysed in the following article. A dialogue is generally considered as the best form of communication and conflict resolution in building relationships. When dialogue is sought, it is often clear that communication, consensus and agreement are sought (Buber, 2001; Gutauskas, 2010). The philosophy of dialogue was very important in analysing possibilities for cooperation, adapting the content and methods of education, and creating interaction between the participants in the educational process in distance learning during the Covid-19 lockdown. The research was conducted in October and November 2020. A targeted, criteria selection of research participants was applied. The main criterion was pre-primary education teachers who worked remotely in the spring of 2020 during the Covid-19 lockdown. An invitation to participate in the research was sent to all educational institutions in the city of Klaipeda (Lithuania) that provided pre-primary education. Research participants. Fifteen pre-primary education teachers from Klaipeda who worked remotely in the spring of 2020 during the Covid-19 lockdown agreed to participate in the research. The demographic characteristics of the research participants are presented in Table 1. The range of age and qualifications of the study participants allows us to expect the validity of the research data. 
Table 1. Demographic characteristics of informants.

\begin{tabular}{|l|l|l|l|l|}
\hline Informants & Gender & Age & Pedagogical experience & Qualification category \\
\hline M1 & Female & 34 & 12 & Teacher \\
\hline M2 & Female & 42 & 9 & Teacher \\
\hline M3 & Female & 34 & 9 & Senior teacher \\
\hline M4 & Female & 48 & 25 & Methodologist \\
\hline M5 & Female & 59 & 40 & Teacher \\
\hline M6 & Female & 61 & 42 & Teacher \\
\hline M7 & Female & 60 & 40 & Methodologist \\
\hline M8 & Female & 56 & 32 & Methodologist \\
\hline M9 & Female & 48 & 26 & Methodologist \\
\hline M10 & Female & 45 & 21 & Methodologist \\
\hline M11 & Female & 66 & 43 & Methodologist \\
\hline M12 & Female & 50 & 22 & Senior teacher \\
\hline M13 & Female & 64 & 45 & Senior teacher \\
\hline M14 & Female & 57 & 33 & Senior teacher \\
\hline M15 & Female & 48 & 16 & Methodologist \\
\hline
\end{tabular}

Data collection and analysis. The participants in the research were sent a research consent form, which contained all the information related to the organisation of the research: the research aim, process, an assurance of confidentiality, the duration of the research, etc. After receiving signed consent, the research time was agreed on with each participant. The semi-structured interview was conducted remotely using the Zoom application. Conversations were recorded. The total duration of interviews is more than eight hours, and 65 pages of transcribed text. Confidentiality is maintained, the personal data of the research participants were depersonalised, and the research materials are available only to the researchers. The research data were processed using qualitative content analysis. Each transcribed text was read by the group of researchers. The text was read to form an overall picture, and essential sentences or parts of them related to the analysed topic were singled out. The text was divided into meaningful units that are represented by phrases, sentences and key words which are directly related to the analysed phenomenon; meaningful units were grouped, in order to combine them into an overall structure. 'When reviewing the structure, it is checked whether all transformed meaningful units are included, whether more general ones include composite meaningful units' (Čepienè, Teresevičienè, 2010: 78). Further questions were once again clarified with the research participants. After the research report was prepared, the informants were offered the chance to get acquainted with it. The informants provided no comments. When presenting the research findings, statements were coded, e.g. M1, M2, etc. The grammar of the teachers' statements was not changed. The research data are systematised from three points of view: educational situation after the declaration of lockdown in an educational institution - the initial reaction and adaptation of the administration and teachers of the educational institution; peculiarities of the distance education process - educational content, organisation of the educational process, children's achievements and progress, feedback; experiences of participants in education, advantages and disadvantages of distance pre-primary education; steps in planning distance education in the future. The following article presents only part of the research findings: peculiarities of the distance education process - educational content, organisation of the educational process; children's achievements and progress, feedback.

In the implementation of the research, principles of ethics were ensured. Confidentiality: the personal data of research participants are not disclosed, they are provided in the reports as encrypted and known only to researchers. Fairness: the research data are analysed in accordance with the methodology of the qualitative analysis, they are presented undistorted, and interpretations are made by presenting the direct text of the informants. Voluntariness: participation in the research was voluntary for the research participants. 


\section{Results of empirical research}

The research sought to find out the experiences of pre-primary education teachers while working remotely after the declaration of lockdown in Lithuania due to Covid-19, and how the assessment of children's achievements and progress in the ensuing situation was organised. An analysis of informants' statements allows us to distinguish the two main tools used by teachers for distance learning: information and communication technology (ICT), and traditional tools. The ICT tools used comprise the following four groups: online platforms and social networks; digital software; software for creating teaching materials and educational games; smart digital devices (Figure 1). The traditional tools include tasks in exercise books, various work from aids, tasks that train fine and general motor skills, etc.

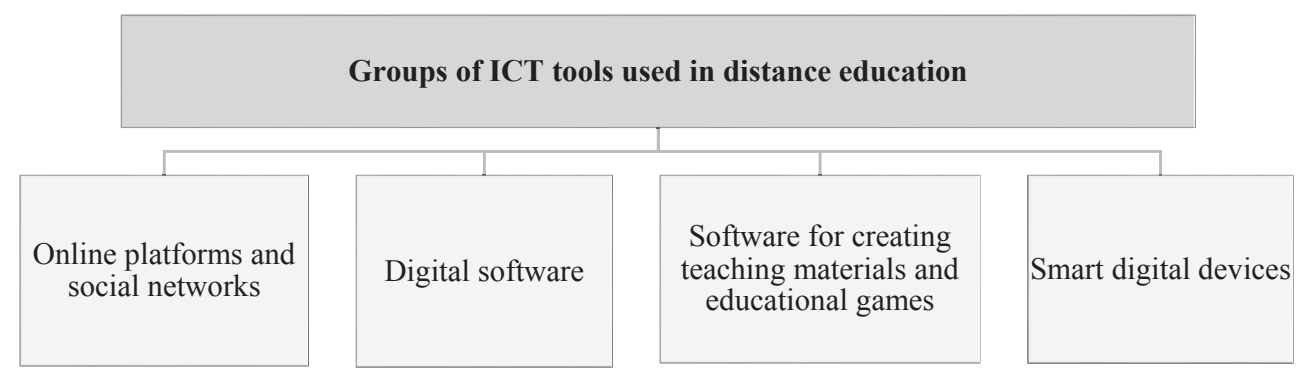

Figure 1. Groups of ICT tools used by teachers for distance learning

Most of the informants emphasised ICT tools. Table 2 shows that the vast majority of educators used Facebook groups, created them and invited parents to join, or used parent-created ones (14). Some teachers (4) used the electronic diary Musudarzelis.lt or the electronic learning environments EMA (2) and Eduka. It (1). All the teachers (15) used emails and the Google platform, some (3) used YouTube and Pinterest (1).

Table 2. Online platforms and social networks used in distance learning

\begin{tabular}{|c|c|c|}
\hline Category & Subcategory & Excerpts from interview texts (informant) \\
\hline \multirow{7}{*}{$\begin{array}{l}\text { Online } \\
\text { platforms }\end{array}$} & \multirow[b]{2}{*}{$\begin{array}{l}\text { Electronic diary } \\
\text { musudarzelis.lt }\end{array}$} & 'Contact with parents took place through electronic diary musudarzelis.lt'(M5) \\
\hline & & $\begin{array}{l}\text { 'We later connected to the musudarzelis.lt system and connected all } \\
\text { parents. Not all parents willingly connected, some didn't understand how } \\
\text { to. It took us a week to reach everyone, so that everyone could join and } \\
\text { see plans of the kindergarten'(M8) }\end{array}$ \\
\hline & $\begin{array}{l}\text { Electronic learning } \\
\text { environment EMA }\end{array}$ & $\begin{array}{l}\text { 'We got acquainted with various platforms, with the Ema system. We used } \\
\text { Ema, because it was free, when we connected all parents'(M4) }\end{array}$ \\
\hline & $\begin{array}{l}\text { Electronic learning } \\
\text { environment Eduka.lt }\end{array}$ & 'I've always attached more scanned tasks to the Eduka diary files'(M10) \\
\hline & Google & '...we also used other social networks (...) Google, email'(M13) \\
\hline & Pinterest & $\begin{array}{l}\text { '...I collected tasks in the vastness of the Internet starting from Pinterest } \\
\text { to...'(M2) }\end{array}$ \\
\hline & YouTube & $\begin{array}{l}\text { '...I film a topic (...) A colleague films the creative part, sends it to me, } \\
\text { then I combine everything using a program into one lesson and we post it } \\
\text { on YouTube'(M1) }\end{array}$ \\
\hline Social networks & Facebook groups & $\begin{array}{l}\text { 'We created a Facebook group with the chairman of the parent committee. } \\
\text { Parents had their own group, and communicated. We created another } \\
\text { where we could all join'(M5) }\end{array}$ \\
\hline & Email & $\begin{array}{l}\text { 'Our group chose social networks that were easiest and simplest to } \\
\text { manage for all of us, email'(M14) }\end{array}$ \\
\hline
\end{tabular}


Educators used various online programs to maintain close contact with parents and ensure the continuity of the children's education. The most popular and commonly used were Zoom (7) and Messenger (5). Skype (4), Viber (2), WhatsApp (1) and Google drive (2) were also used (Table 3). In developing educational tools, not only did educators use the already-mentioned platforms, but also created teaching materials and games using various digital programs: Padlet.com (5), PowerPoint (2), Bookcreator.com (2), Worldwall.net (2), LearningApps.org (1), Jigsawplanet.com (1), Mudubudu.lt (1).

Table 3. The variety of digital software used in distance learning

\begin{tabular}{|c|c|c|}
\hline Category & Subcategory & Excerpts from interview texts (informant) \\
\hline \multirow{6}{*}{$\begin{array}{l}\text { General digital } \\
\text { software }\end{array}$} & Googledrive & $\begin{array}{l}\text { '...the number of participating parents and children began to decline, } \\
\text { and then we conducted a survey through Googledrive, we created a } \\
\text { profile there'(M1) }\end{array}$ \\
\hline & Viber & 'Private calls usually with the help of Viber'(M11) \\
\hline & WhatsApp & $\begin{array}{l}\text { '...I sent all the materials to a colleague via the WhatsApp application, } \\
\text { because we found out that data is best transferred there, the largest files } \\
\text { can be sent'(M2) }\end{array}$ \\
\hline & Messenger & $\begin{array}{l}\text { 'Individual conversations took place on Viber, Messenger, Zoom } \\
\text { platforms'(M12) }\end{array}$ \\
\hline & Zoom & $\begin{array}{l}\text { 'Communication between parents and children and teachers took place } \\
\text { on the Zoom platform'(M7). }\end{array}$ \\
\hline & Skype & 'We communicated via Skype, by phone'(M13) \\
\hline \multirow{7}{*}{$\begin{array}{l}\text { Digital software for } \\
\text { creating teaching } \\
\text { materials and } \\
\text { educational games }\end{array}$} & Bookcreator.com & 'We got acquainted with Bookcreator, all these kinds of tools'(M4) \\
\hline & Worldwall.net & $\begin{array}{l}\text { 'Use of the Wordwall application in pre-primary and pre-school } \\
\text { education'(M11) }\end{array}$ \\
\hline & LearningApps.org & $\begin{array}{l}\text { '...LearningApp', it's sometimes that it can create only a certain amount } \\
\text { of free games'(M1) }\end{array}$ \\
\hline & Jigsawplanet.com & $\begin{array}{l}\text { '...on Friday we created some kind of game for children, for example } \\
\text { Jigsawplanet (...) we put some picture of the group, so that they } \\
\text { remember their friends and (...) they have to put together that puzzle, } \\
\text { (M1) }\end{array}$ \\
\hline & Mudubudu.lt & '...it's possible to find tasks in Mudubudu'(M2) \\
\hline & Padlet.com & $\begin{array}{l}\text { '...we used the 'Padlet' board to reveal feedback and for parents to see } \\
\text { each other'(M3) }\end{array}$ \\
\hline & PowerPoint & '...we daily created a lesson using the PowerPoint application'(M3) \\
\hline
\end{tabular}

As can be seen in Table 3, educators used a wide variety of digital applications, not only to keep in touch with children and their parents, but also to create teaching materials and educational games.

When asked about smart devices used for remote work, it was established that all teachers (15) used personal mobile phones, almost all (14) used computers, and a small part (2) used tablets, e.g., 'The main tools were a computer, a tablet and a smartphone'(M15). Several informants (2) mentioned that they had an opportunity to take a computer home from the educational institution (but it was not necessary), e.g., 'We used our phones. If a computer was needed, it was possible to take one from the kindergarten'(M5), and one (1) informant said that one had to work using a personal phone and a tablet only, e.g., 'The kindergarten did not provide a computer. So I had a tablet. So a phone, a tablet were the main tools. We used our personal tools'(M9).

The majority of respondents (11), in addition to ICT tools, used traditional ones: 'Opa Pa' exercise books (11), e.g., 'We worked according to the 'Opa Pa' methodology'(M6), task books (7), other aids (11) for drawing, writing, training of fine and gross motor skills, musical and non-formal education, e.g., 'I indicated what pages should be completed from the task notebook that children had at home. I shared morning exercises, audio tales and poems that were required according to the teaching material to a closed FB group... '(M10). 
In order to find out whether educational goals have changed, it was established that educational goals did not change in principle (4), e.g., 'No, educational goals didn't change' (M4). However, they were adjusted by taking into account the current situation (9), e.g., 'We adjusted the goals by taking into account the fact that not all activities could be implemented ... '(M3). A small number of teachers (2) indicated that the goal had changed, e.g., 'The educational goal changed, because parents had to be actively involved in education, participate in performing various tasks. There was no direct contact with children'(M7).

Teachers adjusted the content primarily by taking into account the fact that parents would be able to transmit educational tasks to their children, and the process of children's education would be continuous and purposeful in order to achieve findings provided in the General Curriculum Framework for Pre-primary Education (2014).

In order to reveal teachers' experiences about the assessment of children's achievements and progress, it can be identified that some teachers (5) were happy that lockdown was declared already at the end of the school year and teachers knew the level of children's competencies, e.g.: 'It was easier only because it was already the end of the year, we already knew the children, we knew their abilities, what they are capable of, what they know'(M4). All the teachers said that they assessed children's achievements and progress after returning from lockdown to contact work (15), e.g., '...we assessed in May, we have taken time to assess. We simply observed the situation and waited for what would happen'(M1); 'Since only some of the children returned, because not all the children returned, it was easier to assess the achievements, progress of those children, as you can provide tasks. It was more difficult to assess those who did not return, but it had to be done, because recommendations also had to be written to the school'(M3).

The analysis of informants' statements revealed seven main aspects of the situation with the assessment of children's achievements and progress (Table 4).

Table 4. Teachers' opinions of the situation with the assessment of children's achievements and progress during distance learning

\begin{tabular}{|c|c|c|}
\hline Category & Subcategory & Extracts from interview texts (informant) \\
\hline Complicated & - & $\begin{array}{l}\text { '... actually, it's quite difficult to assess remotely...'(M1); 'It wasn't that I } \\
\text { could easily assess achievements, it was difficult'(M8); '... because there was } \\
\text { no direct contact with the child and it wasn't possible to observe children's } \\
\text { abilities in various activities'(M7); 'Distance learning made it difficult to } \\
\text { assess, because you don't see how the child performs the task'(M3) }\end{array}$ \\
\hline $\begin{array}{l}\text { Did not know how } \\
\text { to do it }\end{array}$ & - & $\begin{array}{l}\text { 'In fact, I didn't even have an idea how well to accurately assess, that it would } \\
\text { be correct at a distance'(M1) }\end{array}$ \\
\hline Observed & - & 'We simply observed the situation and waited for what would happen'(M1) \\
\hline $\begin{array}{l}\text { Put all hopes } \\
\text { in parental } \\
\text { involvement }\end{array}$ & - & $\begin{array}{l}\text { 'In the situation at that time, children's educational outcomes depended on } \\
\text { parents' attitude, interest in learning activities and the work done (M10); } \\
\text { It depends a lot on the parents, how they see it (M6); '...it depended on the } \\
\text { parents'willingness to help their child'(M5) }\end{array}$ \\
\hline \multirow[t]{2}{*}{$\begin{array}{l}\text { Children's results } \\
\text { depended on the } \\
\text { involvement and } \\
\text { attitude of parents }\end{array}$} & Positive & $\begin{array}{l}\text { 'Those parents who helped their children, who worked with their children, so } \\
\text { the progress of those children was felt, it increased, there was a result'(M9); } \\
\text { 'There were several children who had not yet succeeded in combining the } \\
\text { letters into a syllable, and mothers, after consulting with the group teacher } \\
\text { and by applying a variety of ways, were able to teach children to read' } \\
\text { (M10); 'If parents paid attention, worked with children, then achievements } \\
\text { really improved'(M5); 'I noticed that those families who focused on teaching } \\
\text { children, the results of their children were significantly better'(M13) }\end{array}$ \\
\hline & Negative & $\begin{array}{l}\text { 'But those children whose parents didn't work with them and left them to the } \\
\text { will of fate didn't make progress'(M9); 'It is obvious that those who didn't } \\
\text { show feedback and achievements were lower'(M10); 'Not all parents had the } \\
\text { opportunity, or perhaps conditions, desire, to share the results achieved }\end{array}$ \\
\hline
\end{tabular}




\begin{tabular}{|c|c|c|}
\hline Category & Subcategory & Extracts from interview texts (informant) \\
\hline & & $\begin{array}{l}\text { by children, there was a lack of feedback'(M7); 'Several children were taken } \\
\text { to their grandparents during that period. And grandparents didn't master } \\
\text { any smart technologies. The achievements of those children are lower'(M6); } \\
\text { 'There were also those who said that now they don't have time, are tired, have } \\
\text { other work, the achievements of those children are lower'(M5) }\end{array}$ \\
\hline $\begin{array}{l}\text { Children's } \\
\text { achievements } \\
\text { and progress are } \\
\text { recorded on the } \\
\text { basis of feedback } \\
\text { provided by parents }\end{array}$ & - & $\begin{array}{l}\text { '...we were able to observe educational results from feedback, when parents } \\
\text { uploaded photos and videos with completed tasks (photographed completed } \\
\text { exercise pages, reading, hand training exercises, sports, nature exploration, } \\
\text { etc) to the FB group'(M10); 'We saw in the exercises, parents sent videos } \\
\text { that they read better, photos of works, calculation tasks. Conversations with } \\
\text { parents'(M5); 'The most effective way, in my case, proved to be individual } \\
\text { conversation by phone, on social networks via the Messenger application' } \\
\text { (M15) }\end{array}$ \\
\hline $\begin{array}{l}\text { Provided feedback } \\
\text { to children }\end{array}$ & - & $\begin{array}{l}\text { 'Of course, I assessed each work with a comment for the child'(M10); 'Every } \\
\text { time I received work, I sent children "suns", "smiles”, icons "you're great", } \\
\text { etc, to encourage, assess children's efforts'(M8) }\end{array}$ \\
\hline
\end{tabular}

According to educators, when assessing the impact of distance learning on children's achievements and progress, distance learning affected the results (8), e.g., 'I had a foreign boy and a separate program was applied to him, so when he returned, he stopped speaking Lithuanian. It was a step backwards'(M9); '...in kindergarten children would have been more prepared'(M1); 'Educational outcomes were partly affected' (M7); 'The achievements of some children have been affected, of some - have been improved'(M5); '...I think there is, because after all when you organise activities, there is also teamwork, so I believe it's a disadvantage, because children didn't have that and couldn't perform exactly those tasks, or not. There was no communication with each other, development of social relations'(M3); '...it wasn't possible to virtually identify learning gaps of my pre-schoolers or reasons how and why they occurred'(M15).

Pre-primary education teachers (2) believe that social skills were particularly affected, e.g., '...there was a serious lack of direct communication, hugging, smiles' (M8); '...children's communication, interaction were affected'(M14).

\section{Conclusions}

The findings of the qualitative research revealed that the organisation of distance education after the declaration of lockdown in Lithuania posed new challenges for all participants in pre-primary education: the administrators of educational institutions, teachers and parents. However, educators tried not to change, and to achieve the goals set in the 'General Curriculum Framework for Pre-primary Education'. It can be claimed that teachers performed their duties in the best way available to them: they managed to master quickly digital software and information flows, cooperate with colleagues and parents of children, maintain the continuity of pre-primary education, and individually take into account the situation of each child. Teachers used ICT and traditional tools for the implementation of distance learning. They managed to integrate educational methods: they worked using the 'Opa Pa' pre-primary education toolkit. But they developed educational activities using ICT tools: videos, self-created films, digital games, educational tasks, etc.

In order to maintain feedback with parents, teachers used a variety of methods that were easily managed and available to parents: online platforms, social networks, virtual environments and emails, and communicated via direct audio and video connections. Teachers constantly provided parents with individual consultations on all issues related to their children's education.

The research helped to reveal the experiences of pre-primary education teachers in assessing children's achievements and progress when organising distance education. According to teachers, distance education had an impact on children's performance, and especially on social skills, but allowed them to prepare children for school, because the lockdown was declared at the end of the school year. It can be argued that the implementa- 
tion of pre-primary education at a distance and the assessment of children's achievements and progress require a high level of parental involvement. The final assessment of children's achievements and progress, and the preparation of recommendations for the school, took place after the return to educational institutions.

In summarising the results, the research limitations should also be noted. Even though when planning and conducting the research, the requirements for this type of research were complied with, the generalisation of the research results and their applicability are limited in part by the small number of research participants. It is the results of the qualitative research that are unique and specific to the individuals involved in the research. It would be incorrect to apply the findings of the research to all pre-primary education institutions, but it is likely that the opinions expressed by the participants of the research allow us to understand the experience of pre-primary education teachers in distance learning in assessing children's achievements and progress during the Covid-19 lockdown. The results of the research allow us to predict further possibilities for studying the phenomenon, in order to establish the opinion of primary school teachers working with firstgraders about the impact of distance pre-school learning on pupils' educational results.

\section{References}

Alasuutari, M., Markstrom, A. M. (2011). The making of the ordinary child in preschool. Available at EBSCO: http:// web.a.ebscohost.com/ehost/pdfviewer/pdfviewer?sid=254f8f1f-58c1-4c66-a3a5-c9627dec74e5\%40sessionmgr40 04\&vid=16\&hid=4212 [viewed on: 09.01.2021].

Azevedo, J. P., Hasan, A., Goldemberg, D., Iqbal, S. A., Geven, K. (2020). Simulating the Potential Impacts of COVID-19 School Closures on Schooling and Learning Outcomes: A Set of Global Estimates. Policy Research Working Paper, World Bank Group. Available at: https://doi.org/10.1596/1813-9450-9284 [viewed on: 12.02.2021].

Bertling, J., Rojas, N., Alegre, J., Faherty, K. (2020). A Tool to Capture Learning Experiences During COVID-19: The Pisa Global Crises Questionnaire Module OECD. Education Working Paper, No. 232. Available at: http://www.oecd.org/officialdocuments/publicdisplaydocumentpdf/?cote=EDU/WKP(2020)20\&docLanguage=En [viewed on: 04.02.2021].

Bernotienè, R., Juraitienè, I. (2011). Ikimokyklinio amžiaus vaiku ugdymo pasiekimu vertinimas. Lietuvos ir užsienio šaliu patirtis. Vilnius: Ugdymo plètotès centras.

Boyd, D., Bee, H. (2011). Augantis vaikas. Vilnius: Standartų spaustuvè.

Brenneman, K. (2011). Assessment for preschool science learning and learning environments. Available at EBSCO: http://www.eric.ed.gov/contentdelivery/servlet/ERICServlet?accno=EJ931225 [viewed on: 04.02.2021].

Buber, M. (2001). Dialogo principas II. Vilnius.

Brown, N., Te Riele, K., Shelley, B., Woodroffe, J. (2020). Learning at home during COVID-19: Effects on vulnerable young Australians. Independent Rapid Response Report. Hobart: University of Tasmania, Peter Underwood Centre for Educational Attainment. Available at: http://creativecommons.org/licenses/by/3.0/au/deed.en [viewed on: 04.02.2021].

Creswell, J. W. (2014). Research Design: Qualitative, Quantitative and Mixed Methods Approaches. 4th ed. Thousand Oaks, CA: Sage.

Čepienė, E., Teresevičienè, M. (2010). Fenomenologinė bendrujjų kompetencijų ugdymo perspektyva profesiniame rengime (Verslo vadybos studijų atvejis). Pedagogika, Nr. 98, p. 76-84.

Di Pietro, G., Biagi, F., Costa, P., Karpiński, Z., Mazza, J. (2020). The likely impact of COVID-19 on education: Reflections based on the existing literature and international datasets. Publications Office of the European Union, Luxembourg. Available at: https://publications.jrc.ec.europa.eu/repository/bitstream/JRC121071/jrc121071.pdf [viewed on: 12.02.2021].

Diamond, K. E., Justice, L. M., Siegler, R. L., Snyder, P. A. (2013). Synthesis of IES research on early intervention and early childhood education. Available at EBSCO: http://eric.ed.gov/?id=ED544212 [viewed on: 15.10.2020].

Donohue, Ch., Johnson, A., Lucas, P., Lynd, Ch., Mukerjee, J., Thouvenelle, S. (2020). Distance Learning and Early Childhood Education. Available at: https://eclkc.ohs.acf.hhs.gov/professional-development/article/distance-learning-early-childhood-education [viewed on: 10.02.2021].

Dwivedi, Y. K., Hughes, D. L., Coombs, C., Constantiou, I., Duand, Y., Edwards, J. S., Gupta, B., Lal, B., Misra, S., Prashant, P., Raman, R., Rana, N. P., Sharma, S. K., and Upadhyay, N. (2020). Impact of COVID-19 pandemic on information management research and practice: Transforming education, work and life. International Journal of Information Management, Vol. 55, p. 1-20. Doi: https://doi.org/10.1016/j.ijinfomgt.2020.102211.

Gerde, H. K., Schachter, R. E., Wasik, B. A. (2013). Using the scientific method to guide learning: an integrated approach to early childhood curriculum. Available at EBSCO: http://web.a.ebscohost.com/ehost/pdfviewer/pdfviewer?sid=254f8flf58c1-4c66-a3a5-c9627dec74e5\%40sessionmgr4004\&vid=10\&hid=4212 [viewed on: 20.12.2020]. 
Guidelines on Distance Education during COVID-19. (2020). Commonwealth of Learning. Available at: http://oasis. col.org/bitstream/handle/11599/3576/2020_COL_Guidelines_Distance_Ed_COVID19.pdf?sequence=4 [viewed on: 01.02 .2021$]$.

Gutauskas, M. (2010). Dialogo erdvė: fenomenologinis požiūris. Vilnius: Vilniaus universiteto leidykla.

Ikimokyklinio ugdymo kokybė / Quality of Pre-school Education. (2012). Available at: http://www.nmva.smm.lt/wpcontent/uploads/2012/12/Ikimokyklinio-ugdymo-kokybe-2012-rugs\%C4\%97jis.pdf [viewed on: 24.10.2020].

Indrašienė, V., Žibėnienè, G. (2014). Pasiekimų vertinimas ir įsivertinimas. Vilnius: Mykolo Romerio universitetas.

International Task Force on Teachers for Education 2030, "COVID-19: A global Crisis for Teaching and Learning”. (2020). Available at: https://teachertaskforce.org/knowledge-hub/covid-19-global-crisis-teaching-and-learning [viewed on: 05.03.2021].

Lietuvos Respublikos Vyriausybes programa / Programme of the Government of the Republic of Lithuania. (2020). Available at: https://e-seimas.lrs.lt/portal/legalAct/lt/TAP/3955e800388111eb8c97e01ffe050e1c [viewed on: 24.10.2020].

Masonbrink, A. R., Hurley, E. (2020). Advocating for Children During the COVID-19 School Closures. Pediatrics, Vol. 146, No. 3, p. 1-6. Available at Doi: https://doi.org/10.1542/peds.2020-1440.

Nuotolinis vaiku ugdymas pandemijos dèl COVID-19 metu: grèsmès bei galimybès ekosisteminiu požiūriu" / Project "Distance education of children during the Covid-19 pandemic: threats and opportunities from an ecosystem perspective” (Agreement No. S-COV-20-11). (2020). VU. Available at: https://www.fsf.vu.lt/dokumentai/Dokumentainuorodos/VU_mokslinink\%C5\%B3_projekto_rekomendacijos.pdf [viewed on: 04.02.2021].

Pasiūlymas , Tarybos rekomendacija “ dèl kokybišku ikimokyklinio ugdymo ir priežiūros sistemu. (2018). Europos Komisija / Proposal for a Council Recommendation on High Quality Early Childhood Education and Care Systems. European Commission. Available at: https://eur-lex.europa.eu/legal-content/LT/TXT/?uri=COM\%3A2018\%3A271\%3AFIN [viewed on: 24.10.2020].

Pokhrel, S., Chhetri R. (2021). A Literature Review on Impact of COVID-19 Pandemic on Teaching and Learning. Sage Journals. Available at: https://doi.org/10.1177\%2F2347631120983481 [viewed on: 25.03.2020].

Policy Brief: Education during COVID-19 and beyond. (2020). Available at: https://www.un.org/development/desa/ $\mathrm{dspd} / \mathrm{wp}$-content/uploads/sites/22/2020/08/sg_policy_brief_covid-19_and_education_august_2020.pdf [viewed on: 04.02.2021].

Priešmokyklinio ugdymo bendroji programa / General Curriculum Framework for Pre-primary Education. (2014). Švietimo aprūpinimo centras: Šviesa. Available at: https://www.smm.lt/uploads/documents/ Prie\%C5\%A1mokyklinio\%20ugdymo\%20bendroji\%20programa(3).pdf [viewed on: 25.03.2020].

Ramanauskienė, S., Norvilienė, A. (2017). Optimization of achievements assessment of preschool children. Available at: http://journals.rta.lv/index.php/SIE/article/download/2445/2364 [viewed on: 09.03.2021].

Reimers, F. M. (2020). Educating Students to Improve the World. Springer Briefs in Education (eBook). Available at: https://doi.org/10.1007/978-981-15-3887-2 [viewed on: 10.02.2021].

Sintema, E. J. (2020). Effect of COVID-19 on the Performance of Grade 12 Students: Implications for STEM Education. EURASIA Journal of Mathematics, Science and Technology Education, Vol. 16, No. 7, p. 1-6. Doi: https://doi. org/10.29333/ejmste/7893.

Schleicher, A. (2020). The Impact of COVID-19 on Education Insights From Education at a Glance. Available at: https://www.oecd.org/education/the-impact-of-covid-19-on-education-insights-education-at-a-glance-2020.pdf [viewed on: 17.02.2021].

Tarybos rekomendacija dèl kokybišku ikimokyklinio ugdymo ir priežiūros sistemų / Council Recommendation on Quality Pre - school Education and Care Systems. (2018). Available at: https://eur-lex.europa.eu/legal-content/LT/ TXT/?uri=CELEX:52018DC0271 [viewed on: 17.02.2021].

Technical Note Education during the COVID-19 Pandemic. (2020). Version 1. Inter-agency Network for Education in Emergencies (INEE). Available at: https://inee.org/resources/inee-technical-note-education-during-covid-19-pandemic [viewed on: 04.02.2021].

Verma, G., Priyamvada, R. (2020). COVID-19 and Teaching: Perception of School Teachers on Usage of Online Teaching Tools. Mukt Shabd Journal, Vol. 7, No. 2, p. 90-109. Available at: https://www.researchgate.net/publication/342199884_COVID-19_and_Teaching_Perception_of_School_Teachers_on_Usage_of_Online_Teaching_ Tools/link/5ee876cf458515814a6293c5/download [viewed on: 04.02.2021].

Yoshikawa, H., Wuermli, A. J., Britto, P. R., et al. (2020). Effects of the Global Coronavirus Disease-2019 Pandemic on Early Childhood Development: Short- and Long-Term Risks and Mitigating Program and Policy Actions. The Journal of Pediatrics, Vol. 223, p. 188-193. Available at: https://www.jpeds.com/article/S0022-3476(20)30606-5/ pdf [viewed on: 04.02.2021].

Žydžiūnaite, V., Sabaliauskas, S. (2017). Kokybiniai tyrimai: principai ir metodai. Vilnius: Vaga. 


\title{
PRIEŠMOKYKLINIO UGDYMO MOKYTOJŲ NUOTOLINIO UGDYMO PATIRTYS, IVERTINUS VAIKU PASIEKIMUS IR PAŽANGĄ COVID-19 PANDEMIJOS LAIKOTARPIU
}

\author{
Aida Norviliené, Sada Ramanauskiené, Neringa Strazdienė, Rasa Braslauskienė, Reda Jacynė \\ Klaipėdos universitetas (Lietuva)
}

\section{Santrauka}

COVID-19 pandemija iškèle naujų iššūkių ir galimybių ugdymo dalyviams (ugdymo ịstaigų vadovams, mokytojams, ugdytiniams ir jų tèvams). Pasaulinès pandemijos nulemta staigi ugdymo(si) transformacija leidžia ištirti nuotolinio ugdymo pritaikymo galimybes, siekiant užtikrinti vaikų įsitraukimą, personalizavimo, savalaikio grį̌tamojo ryšio teikimą, vaikų pasiekimų ir pažangos vertinimą, siekiant akademinio vientisumo bei ugdymo kokybès. COVID-19 pandemija iš esmès paveikẻ kiekvieną žmogaus gyvenimo sritị: pradedant ekonomika, medicina, švietimu ir baigiant kasdieniu gyvenimu, socialiniais santykiais, žodynu. Daugelio mūsų kalboje jau kasdieniais tapo tokie žodžiai, kaip (angl.) Teams, Zoom ir pan. (Dwivedi ir kt., 2020). A. R. Masonbrink ir E. Hurley (2020) siūlo atkreipti dèmesi ị tai, kad uždarant ugdymo ịstaigas karantinui svarbu užtikrinti ugdytiniams patikimas prieigas prie technologijų, stabilią mokymosi aplinką, vaikų pasiekimų ir pažangos vertinimą. E. J. Sintema (2020) pastebejjo, kad iki COVID-19 pandemijos moksliniai tyrimai retai kada būdavo nukreipti į pasaulinių pandemijų poveikị ugdymui(si).

Vaikų pažangos ir vertinimo pokyčių, dirbant nuotoliniu būdu, klausimai aptarti ir tyrimų duomenys pateikti F. M. Reimers'o (2020) bei dokumentuose: „Guidelines on Distance Education during COVID-19“ (2020), „Policy Brief: Education during COVID-19 and beyond“ (2020). F. M. Reimers'o (2020) teigimu, COVID-19 situacija ir pokyčiai ugdymo realybejje kelia esminius klausimus profesinejje pedagogų perspektyvoje. Kinta pedagogų atliekamos funkcijos, tiksliau, jos keliasi į virtualią realybę. N. Brown, K. Te Riele, B. Shelley, J. Woodroffe (2020) tikina, kad mokytojai geba tikslingai parinkti mokymosi turini, metodus, kurie atitiktų aiškius mokymo programos tikslus ir vertinimą. Tačiau norint, kad visas mokymo procesas būtų nuotolinis, reikia laiko, nemažai papildomų žinių ir kitų sričių specialistų pagalbos. J. P. Azevedo ir kt. (2020) teigimu, jau dabar COVID-19 pandemijos ir jos nulemtų reiškinių žala vaikų ugdymui(si) aiškiai matoma.

Šiame straipsnyje atskleidžiamos priešmokyklinio ugdymo mokytojų nuotolinio ugdymo patirtys, įvertinus vaikų pasiekimus ir pažangą COVID-19 pandemijos pirmojo karantino metu. Atliekant kokybini tyrimą dalyvavo 15 priešmokyklinio ugdymo mokytojų, kurie $2020 \mathrm{~m}$. pavasarį dirbo nuotoliniu būdu. Tyrimo radiniai atskleide, kad nuotolinio ugdymo organizavimas kẻlè naujų iššūkių visiems priešmokyklinio ugdymo dalyviams. Ugdymo tikslų, numatytų Priešmokyklinio ugdymo bendrojoje programoje, pedagogai stengėsi nekeisti. Jie sugebejjo sparčiai ịvaldyti skaitmenines programas, informacijos srautus, bendradarbiauti su kolegomis ir vaikų tėvais, išlaikyti priešmokyklinio ugdymo tęstinumą, atsižvelgti į individualią kiekvieno vaiko situaciją. Mokytojai, vykdydami nuotolinį ugdymą, taikè informacines komunikacines technologijas (toliau - IKT) ir tradicines priemones. Jiems pavyko integruoti ugdymo metodus: dirbo naudodami „Opa Pa“ priešmokyklinio ugdymo priemonių komplektą, bet ugdomąsias veiklas rengė IKT priemonėmis (vaizdo ịrašais, savo kurtais filmais, skaitmeniniais žaidimais, mokomosiomis užduotimis ir pan.). Grịžtamaji ryši su tèvais palaikè ịvairiais tèvams priimtinais būdais: internetinès platformos, socialiniai tinklai, virtuali aplinka, el. paštas, tiesioginis garso ir vaizdo ryšys. Mokytojai tėvus nuolat individualiai konsultavo visais su vaikų ugdymu susijusiais klausimais.

Tyrimas atskleidė priešmokyklinio ugdymo mokytojų patirtis vertinant vaikų pasiekimus ir pažangą organizuojant nuotolinị ugdymą. Mokytojų nuomone, nors nuotolinis ugdymas paveikẻ vaikų rezultatus ir socialinius ịgūdžius, vis dèlto leido juos parengti mokyklai, nes karantinas paskelbtas besibaigiant mokslo metams. Galima teigti, kad norint priešmokyklinị ugdymą vykdyti nuotoliniu būdu, ịvertinti vaikų pasiekimus ir pažangą, būtinas tèvų issitraukimas. Galutinis vaikų pasiekimų ir pažangos vertinimas bei rekomendacijų 
mokyklai rengimas vyko grịžus ị ugdymo įstaigas. Tyrimo radiniai leidžia numatyti tolesnes šio reiškinio tyrimo galimybes, siekiant išsiaiškinti pradinių klasių mokytojų, dirbančių su pirmokais, nuomones dèl nuotolinio priešmokyklinio ugdymo poveikio mokinių ugdymo(si) rezultatams.

PAGRINDINIAI ŽODŽIAI: COVID-19 pandemija, priešmokyklinis ugdymas, nuotolinis ugdymas, vaiku pasiekimu ir pažangos vertinimas.

JEL KLASIFIKACIJA: I21, I25.

Received: 2021-03-06

Revised: 2021-04-28

Accepted: 2021-05-04 